\title{
MODIFIED CANTWEL-RANSLEY RECONSTRUCTION OF CONTINENT PENILE EPISPADIAS IN CHILDREN: A CASE REPORT
}

\author{
Ahmad Nadhir', Tarmono Tarmono ${ }^{2}$ \\ ${ }^{1}$ Resident of Urology, Faculty of Medicine, Universitas Airlangga, Surabaya, Indonesia/Dr. Soetomo General \\ Academi Hospital, Surabaya, Indonesia \\ ${ }^{2}$ Staff at the Department of Urology, Faculty of Medicine, Universitas Airlangga, Surabaya, Indonesia/Dr. \\ Soetomo General Academic Hospital, Surabaya, Indonesia
}

\begin{abstract}
Epispadias as an isolated embryologic defect is a rare anomaly, with an incidence of 1 in 117.000 males. Isolated epispadias with continence is a very rare condition comprising less than 10\% of all epispadias cases. Epispadias is a closure defect of the dorsal wall of the urethra. The biggest challenges for epispadias treatment are creating adequate penile length, straightening the severely curved penis, and creating a penopubic angle for allowing comfortable penetration of the penis. An 11-year-old boy underwent surgery for his continent penile epispadias in Dr. Soetomo General Academic Hospital. The surgical technique chosen for this patient was Modified Cantwell-Ransley repair. The dressing was opened on the 3rd day after the operation. The urethral catheter was removed on the 10th day. The patients underwent regular follow-up examinations for 6 months and were evaluated for subjective and objective outcomes. There was no post-operative fistula or urethral narrowing requiring urethral dilatation. The Uroflowmetry and post voiding residual ultrasound result was good. The cosmetic appearance of the penis was satisfying. Outcomes related to sexual activity were not evaluated because the patient had no sexual activity yet.
\end{abstract}

Keywords: Modified cantwell-ransley repair; continent; penile epispadias; disease

\section{ABSTRAK}

Epispadia sebagai defek embriologis merupakan kelainan yang jarang, dengan insidensi 1 dari 117.000 laki-laki. epispadias kontinen merupakan kasus yang sangat langka dengan kejadian $<10 \%$ dari seluruh kasus epispadia. epispadias merupakan kondisi pada penis dengan kelainan pada dinding dorsal uretra. Urethra normal digantikan oleh lapisan mukosa luas yang membentang dari dorsum penis ke arah kandung kemih, dengan potensi terjadinya inkompetensi pada mekanisme sfingter. Tantangan terbesar dari penanganan epispadias adalah membuat panjang penis yang adekuat, meluruskan penis dengan kelengkungan yang berat, dan menciptakan sudut penopubik yang memungkinkan penetrasi penis yang nyaman. Seorang anak laki-laki berusia 11 tahun menjalani operasi rekonstruksi epispadias penis kontinen di departemen urologi, RSUD Dr. Soetomo. Teknik operasi yang dipilih untuk pasien ini adalah rekonstruksi Cantwell-Ransley modifikasi. Bebat dibuka pada hari ke-3 setelah operasi. Kateter uretra dilepas pada hari ke-10 setelah operasi. Pasien kontrol rutin dan dievaluasi selama 6 bulan. Tidak didapatkan fistula setelah operasi dan penyempitan urethra yang memerlukan tindakan dilatasi. Hasil uroflowmetri dan USG residu setelah kencing baik. Penampakan kosmetik penis memuaskan. Kemampuan aktivitas seksual yang memadai tidak dapat dinilai karena faktor usia.

Kata kunci: Rekonstruksi cantwell-ransley; kontinen; epispadias penis; disease

Correspondence: Tarmono, Staff at the Department of Urology, Faculty of Medicine, Universitas Airlangga, Surabaya, Indonesia/Dr. Soetomo General Academic Hospital, Surabaya, East Java 60286. Email: tar_urology@yahoo.com

pISSN:2355-8393 • eISSN: 2599-056x • doi: 10.20473/fmi.v57i3.24357

• Fol Med Indones. 2021;57:262-266• Submitted 07 Jan 2021 • Received 03 Feb 2021 • Accepted 27 Jun 2021

- Open access under CC-BY-NC-SA license • Available at https://e-journal.unair.ac.id/FMI/ 


\section{INTRODUCTION}

Epispadia is an extremely rare embryological defect, with an incidence rate of 1 out of 117,000 males. Continent epicpadia is an extremely rare case with an incidence of $<10 \%$ of all cases. epispadias consists of abnormalities in the dorsal urethra wall. The normal urethra is substituted by a mucosa layer that extends from the dorsum of the penis to the bladder. epispadias patients usually have a short, flat penis with a large dorsal mucosa with a dorsal urethral indentation widened at the base. The glans penis is open and flattened with the meatus at the dorsal shaft of the penis (Gearhart \& Mathews 2016a).

The greatest challenge of treating epispadias is creating an adequate penis length, straightening the penis with heavy curvature, and a penopubic angle that would allow comfortable penile penetration. Another challenge is to provide adequate skin when straightening and lengthening the penis. In some cases, epispadias can be improved by a combination of chordee release and urethroplasty in one stage. However, in many cases this requires a multi-phasic approach. epispadias reconstruction must be performed with the utmost care to achieve excellent functional and cosmetic results (Djordjevic et al 2013).

There are many surgical techniques that have been performed to reconstruct epispadias in men (Giron et al 2017), for which a modified Cantwell-Ransley reconstruction is the procedure of choice in our center. We reported an 11-year-old boy with continent penile epispadias underwent a modified Cantwell-Ransley reconstruction. This case report had received a certificate of ethical clearance form Medical Research Ethical Committee at Dr. Soetomo General Academic Hospital with a decree No. 0135/LOE/301.4.2/X/2020.

\section{CASE PRESENTATION}

TA 11-year-old boy with complaints of a urinary hole in the back of the penis was brought to the Urology Policlinic at Dr. Soetomo General Academic Hospital. Previously, the patient came to a general practitioner for circumcision, however he was advised to go to the Urology Policlinic at Dr. Soetomo General Academic Hospital. The patient complained of the urinary opening in the back of the penis since birth. He described his micturition as clear yellow urine, not dripping, not straining and urinating forward. In the morning, there was no any apparent bending of the penis. The antenatal and labor history were normal.
Physical examination showed that the body weight was $32 \mathrm{~kg}$, height $137 \mathrm{~cm}$ with a Body Mass Index of 17.05. His general condition was adequate with Karnofsky's score of $90 \%$. Generalist status examination did not reveal anemia, jaundice, cyanosis and dyspnea. Physical examination of the thoracic and abdomen showed no abnormalities.

Examination of urological status indicated that there was no mass in the flank region, no renal knock pain, empty bladder, male external genitalia, no circumcision, external urethrae meatus found on the dorsal penis, no bent penis was found. The testicles were both palpable with normal size and shape (figure 1). Laboratory tests showed hemoglobin $13.9 \mathrm{~g} / \mathrm{dL}$, leukocytes $10.2 * 103$ / $\mathrm{uL}$, platelets $341 * 103$ / uL with normal kidney function blood urea nitrogen (BUN) $9 \mathrm{mg} / \mathrm{dl}$, serum creatinine $0.52 \mathrm{mg} / \mathrm{dL}$, and normal liver function. Urine examination showed a $\mathrm{pH}$ of 6.5 , erythrocytes 0.2 per field of view, and leukocytes 0.6 per field of view.

Examination of gram staining on urine preparations obtained the formation of gram-positive coccus bacteria with culture results resulting in Streptococcus oralis with a colony count of $15 \times 104 \mathrm{cfu} / \mathrm{ml}$. Antibiotic sensitivity test resulted in Beta-Lactam Penicilin, Penicilin G, Oxacillin Nitrofurantoin, Sulfa Trimetrhoprim, Erthromycin, Clindamycin, and Levofloxacin sensitive. Chest X-ray showed that the cardiac and pulmonary images were within normal limits. Abdominal ultrasound examination of the abdomen showed no abnormalities.
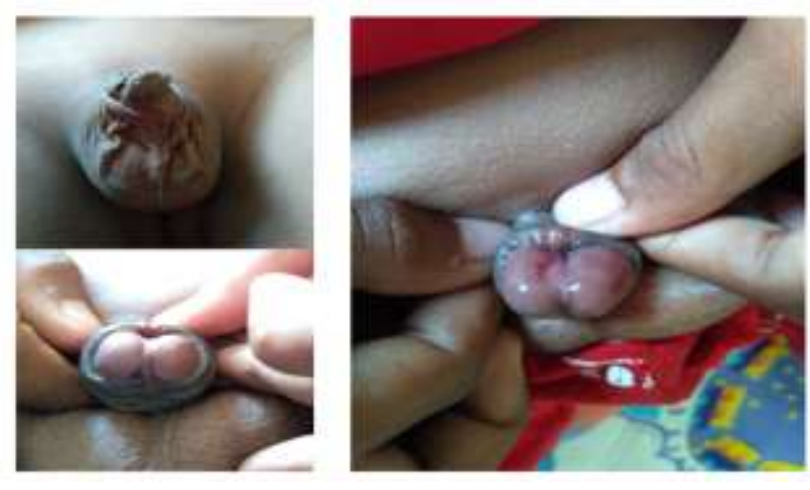

Figure 1. Clinical presentation of the patient

The patient was diagnosed with continent penile epispadias and was planned for urethrocystoscopy and a modified Cantwell-Ransley reconstruction under general anesthesia. The urethrocystoscopy showed normal urethral sphincter and bladder. Modified Cantwell-Ransley reconstruction was performed as shown in Figure 2. The surgical procedure involves placing traction sutures on the glans penis. The urethral 
meatus was transferred ventrally and glanuloplasty was performed on the distal urethral plate. After incision of the urethra on the lateral side, the skin was removed to make a glans wing. The urethral tubularization was formed by a continuous suture (polydiaxanone 6-0) over the 6 fr urethral catheter. Then, the corpora were closed over the neourethra with 2 continuous sutures using polydiaxanone $6-0$, the diamond-shaped defect near the corpora was also sewn together. The glans wing and skin were held together with interrupted sutures using polydiaxanone 6-0.

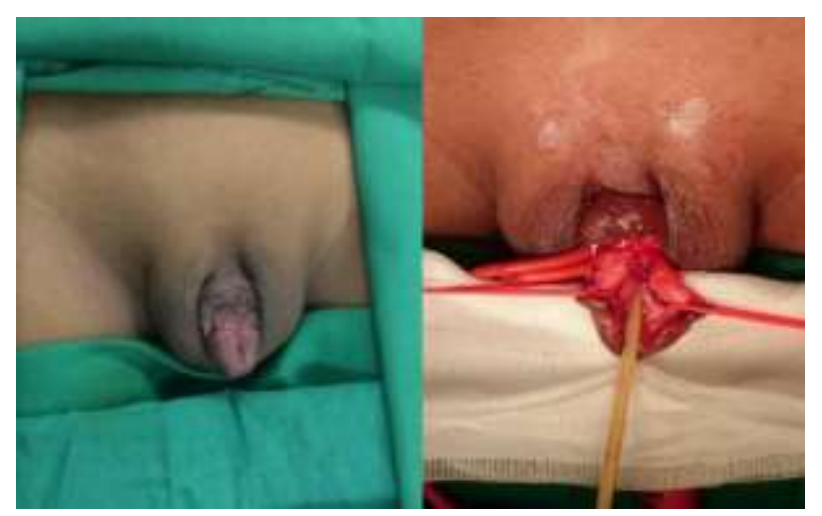

Figure 2. Cantwell-Ransley Modified Reconstruction (left image: pre-operative, right image: Durante operation)

The 6Fr catheter was installed. Postoperatively, the patient was treated for five days, after which the patient was discharged and monitored as an outpatient. Postoperative follow-up included penile dressing removed on day $3,6 \mathrm{Fr}$ catheter removal on day 10 , uroflowmetry performed two weeks after catheter removal (day 24). Evaluation results, 24 days after the surgery showed that the surgical wound had dried up. There was no fistula and urine emission through the external urethral meatus was adequate and the shape of the penis was cosmetically acceptable. The uroflowmetry examination in figure 3 was performed two weeks after removing the catheter in day 24 , it was found that the voided volume was $181 \mathrm{ml}$, Q $\max 8.7 \mathrm{ml}$ / s, post void residual (PVR) $27.7 \mathrm{ml}$.

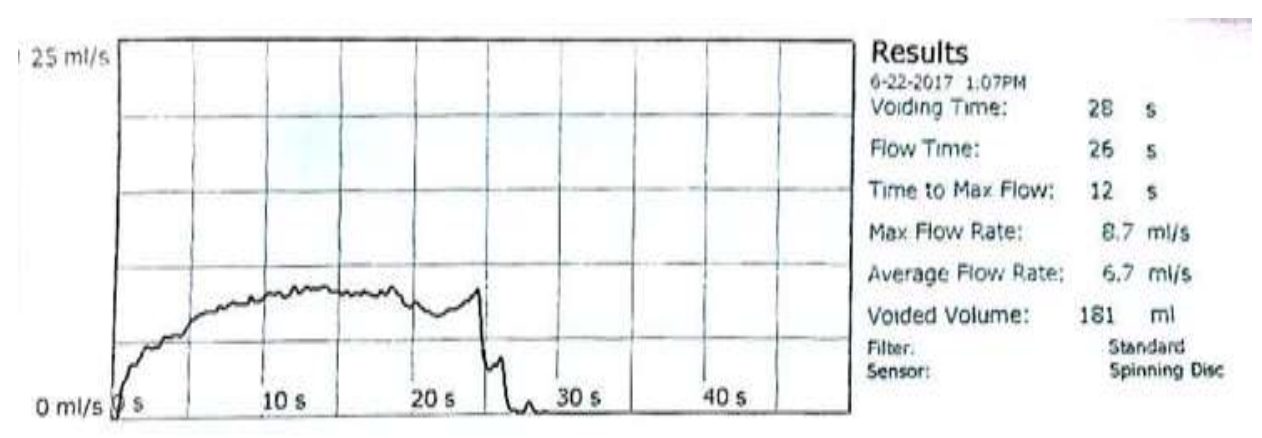

Figure 3. Uroflowmetry examination performed 2 weeks after catheter removal (day 24)

The postoperative results of the evaluation in the $3 \mathrm{rd}$ and 6th month (Figure 4) did not show any fistulas. Urine output through the external urethral meatus was adequate and did not require urethral dilatation Penile shape was cosmetically acceptable. Evaluation of sexual activity cannot be assessed because of age.

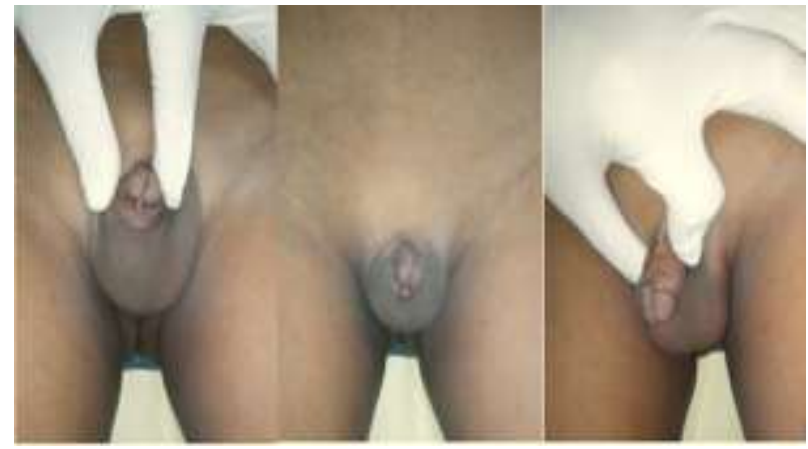

Figure 4. Postoperative evaluation at 6 months 


\section{DISCUSSION}

Epispadias is a rare embryological defect (Beaman et al 2021). The penis in epispadias patients is short and flat, with a broad dorsal mucosal and an indentation of the dorsal urethra as well as widening at the base (Yachia, 2007). The glans of the penis is open and flush with the meatus at the dorsal shaft of the penis. In children, usually the dorsal part of the prepuce is absent. In the case of pure epispadias, the urethra is along the dorsum of the penis, ending somewhere in the shaft of the penis. In most cases the patient is still continent. The urethral opening can be in the glans, dorsal, penopubic surface of the penis. Nearly all patients with glanular epispadias have a competent and continent bladder neck. In penopubic epispadias there is a relatively high percentage (up to $70 \%$ ) of bladder neck and sphincter incompetence which results in incontinence (Gearhart \& Mathews 2016b).

The penis size in epispadias patients varies, but always significantly shorter than the average penis size (Moriya et al 2016). The short penis and severe dorsal curvature adversely affect the patient's ability to have sexual intercourse (Cwikla \& Yafi 2018). For this reason, surgical reconstruction must be performed with care. Most epispadias patients do not suffer from erectile dysfunction once the blood supply to the corpora is not injured during urethral reconstruction, penile lengthening, and penile straightening. The main goal of surgical reconstruction is to straighten the penis, create a penis that is cosmetically acceptable, and of reasonable length to allow sexual intercourse with adequate penetration. epispadias with a short and flat penis accompanied by severe dorsal curvature indicates that surgical reconstruction is rarely able to reach normal penis size (Yachia, 2007).

Several surgical reconstructions have been described to date, but they are far from ideal, so that the improvement of surgical technique is still a challenge (Lodh et al 2013). The aim of surgery was to achieve a penis both functionally and cosmetically acceptable (Nerli et al 2015). Cantwell was the first to perform epispadias repair surgery in 1958 and the technique has gone through many modifications (Nerli et al 2015).

Cantwell-Ransley reconstruction is the most popular technique for epispadias reconstruction compared to the other techniques. Cantwell-Ransley reconstruction consists of mobilization of the urethral plate from the underlying corpora and corporeal lengthening by dividing the suspensory ligament and its attachment to the lower surface of the pubis. This is followed by longitudinally separating the corpora from one to another and making a horizontal incision in the tunica albuginea at its most concave for corporeal alignment. Neourethra is made from the prepuce tube of the ventral pedicle and glanular tubularization by passing through the proximal end of the neourethra through separation between the corpora to anastomose it to the original urethra. Then, a caverno-cavernostomy rotation is then performed for curvature correction. If the curvature is not highly strong, a rotational corporoplasty may be performed to straighten the penis without a tunica incision followed by a closure of the foreskin.

If no penile skin was available, a scrotal skin flap could be used to cover the penis. If the entire surface of the penis is to be covered, this can be done by placing the entire shaft of the penis against the anterior surface of the scrotum for three months and then wrapping the anterior scrotal skin around the shaft of the penis. This approach has the advantage of keeping the penis base in a downward position during healing of the fibrotic attachment to separate the pubis. The cosmetic glans repair can be continued until the final stage of the overall repair. The shape of the glans penis provides important psychological significance for the patient (Yachia 2007). Despite its drawbacks, the distal portion of the urethral plate and corpora cavernosa is not cut and removed which could result in inadequate ventralization of the fistula dan meatus formation at the level of the coronal sulcus.

To avoid the weaknesses of the Cantwell-Ransley technique, Gearhart and Matthews (2016a) described a Cantwell-Ransley modification in the form of dissection of the urethral plate mucosa of $1-1.5 \mathrm{~cm}$ from the most distal corpus so that the urethra is located deeper below the corpus at the glans level (Nerli et al 2015). Using the Cantwell-Ransley technique method, Gearhart and Matthews (2016a) claimed that they were able to achieve orthotopic conical meatus without any ischemic changes in the glans. The modified Cantwell-Ransley technique was also used by Otele et al (2020) in 67 patients where urethroplasty had previously failed.

Pure epispadias cases only affects the urethra. However, in some cases bladder neck involvement are apparent. The sphincter mechanism could be affected by a defect occurring proximal enough to cause urinary incontinence. Two cases of epispadias treated by Bansal et al (2015) had continence that maintained after surgery in both cases. Approximately, $70 \%$ of men with penopubic epispadias have wide separated pelvic bones affecting the external sphincter and bladder neck causing incontinence (Gearhart \& Mathews 2016b).

Complications of epispadias reconstruction surgery include urethrocutaneous fistula formation, persistent cord, difficulty of urethral catheterization and erectile 
dysfunction. Cantwell-Ransley reconstruction fistula rate varies from $5-20 \%$ (Mokhless et al 2008). Nerli et al (2015) treated 43 cases of epispadias with the modified Cantwell-Ransley technique had a fistula rate of $16.27 \%$ (Nerli et al 2015). Gearhart and Mathews (2016b) reported $4 \%$ fistula rate and $5.3 \%$ urethral stricture rate. Lodh et al reported 2 cases of epispadias reconstruction with modified Cantwell-Ransley method, resulting in no fistulas or postoperative dilation measures.

One patient had a superficial infection of the skin of the dorsal penis healed with secondary wound healing without any secondary procedures required (Lodh et al 2013). In the study of Nerli et al (2015), there were 43 cases that treated with this technique resulting in 3 patients with dorsal skin infections. The infection was treated in conjunction with secondary wound healing and did not require further surgery. Salle et al (2002) also used ventral rotation and skin flaps in 9 patients for dorsal skin closure, cosmetic improvement and decreasing secondary cord incidence, because the scar was on the dorsal midline.

Cosmetic evaluation of the penis after reconstruction is a subjective and distinct measure for both the surgeon and the patient. Lottmann et al (1999) reported that $90 \%$ of the 40 treated patients had good functional and anatomical result after surgery with a mean follow-up of 3 years. The patient in this report was evaluated for six months and was presented with satisfactory cosmetic anatomical and functional results. The patient had an acceptable conical glans. There was no postoperative fistula and narrowing of the urethra requiring dilation. The cosmetic appearance of the penis was satisfying. The uroflowmetry test results were also adequate. Unfortunately, the sexual activity ability of the patient could not be assessed yet due to age.

\section{CONCLUSION}

Continent penile epispadias is a rare case. The challenge in epispadias reconstruction is to make the penis adequate in length, straight and with a penopubic angle allowing comfortable penetration. Various types of surgical techniques had been used for the reconstruction of epispadia. The modified Cantwell-Ransley reconstruction has become the preferred procedure, because it provides excellent anatomical and functional results. The complications of epispadias reconstruction surgery included urethrocutaneous fistula formation, persistent cord, difficulty urethral catheterization and erectile dysfunction.

\section{REFERENCES}

Bansal D, Rathore RS, Eillai B, et al (2015). Modified cantwell-ransley repair in penopubic epispadias with continent bladder. Astrocyte 2, 49-51.

Gearhart JP, Mathews R (2016a). Male epispadias. In: Wein AJ (ed). Campbell-walsh urology: 11th ed. Saunders Elsevier, Philadelphia.

Gearhart JP, Mathews R (2016b). C139 exstrophyepispadias complex incidence and inheritance. In: Wein AJ (ed). Campbell-walsh urology: 11th ed. Saunders Elsevier, Philadelphia.

Lodh B, Khumukcham Amer B, et al (2013). Modified cantwell-ransley repair of male penopubic epispadias: Report of two cases and review of the literature. Journal of Case Reports 3, 344-348.

Lottmann HB, Yaqouti M, Melin Y (1999). Male epispadias repair: Surgical and functional results with the Cantwell-Ransley procedure in 40 patients. Journal of Urology 162, 1176-80.

Mokhless I, Youssif M, Ismail HR, et al (2008). Partial penile disassembly for isolated epispadias repair. Urology 71, 235-8.

Nerli RB, Pujar VC, Patil RA, et al (2015). Modified Cantwell-Ransley epispadias repair in children our experience. Journal of the Scientific Society 42, 7-11.

Salle JLP, Jednak R, Capolicchio JP, et al (2002). A ventral rotational skin flap to improve cosmesis and avoid chordee recurrence in epispadias repair. BJU International 90, 918-23.

Yachia D. (2007). Text Atlas of penile surgery. CRC Press, Boca Raton.

Otele WH, Miima S, Owilla F, et al (2020). Efficacy of revision urethroplasty in the treatment of recurrent urethral strictures at a tertiary hospital (Kenyatta National Hospital-KNH), in Nairobi Kenya: 20152018. Bali Medical Journal 9, 67-76.

Cwikla DJ, Yafi FA (2019). Intralesional collagenase Clostridium histolyticum in the management of Peyronie's disease: Current best practice. Therapeutic Advances in Urology 10, 139-153.

Djordjevic ML, Bizic MR, Martins F, et al (2013). Treatment for failed epispadias repair presenting in adults. J Urol 190, 165-70.

Giron AM, Mello MF, Carvalho PA, et al (2017). One staged reconstruction of bladder exstrophy in male patients: long - term follow-up outcomes. Int. Braz. J. Urol 43, 155-162.

Moriya K, Nakamura M, Nishimura Y, et al (2016). Factors affecting post-pubertal penile size in patients with hypospadias. World Journal of Urology 34, 13171321.

Beaman GM, Cervellione RM, Keene D, et al (2021). The genomic architecture of bladder exstrophyepispadias complex. Genes 12, 1-12. 